\title{
Editorial
}

\section{Organic Food}

\author{
Ewelina Hallmann
}

check for updates

Citation: Hallmann, E. Organic Food. Appl. Sci. 2021, 11, 6780. https:// doi.org/10.3390/app11156780

Received: 13 July 2021

Accepted: 21 July 2021

Published: 23 July 2021

Publisher's Note: MDPI stays neutral with regard to jurisdictional claims in published maps and institutional affiliations.

Copyright: (C) 2021 by the author. Licensee MDPI, Basel, Switzerland. This article is an open access article distributed under the terms and conditions of the Creative Commons Attribution (CC BY) license (https:// creativecommons.org/licenses/by/ $4.0 /)$.
Department of Functional and Organic Food, Warsaw University of Life Sciences, Nowoursynowska 159c, 02-776 Warsaw, Poland; ewelina_hallmann@sggw.edu.pl

The present book contains issues connected with a wide understanding of organic food production and quality. In the articles, authors present their own experiments and investigation methods, as well as results. The following sections are included: the quality of organic and conventional fruits (strawberry, apple, rosehip), vegetables, herbs and medicinal plants (white and black garlic, basil, bear's garlic, marjoram, oregano, fireweed, different grains), as well as fruit juices.

Drying methods are one of the most well-known food processing methods. Different and very modern technologies are needed to obtain final products of high quality. Many experiments have shown that organic strawberries contain high levels of bioactive compounds. Therefore, with a proper drying method, it is possible to produce strawberry powder with a high bioactive compound content [1]. Additionally, organic farming practices have a significant impact on the flavonoid and vitamin contents in apple flesh. Both proper cultivars and production systems (organic) give great results for a higher content of polyphenols in apple cultivation [2]. It is also worth giving attention to lesser-known fruits, such as rosehip. The present results showed that rosehips should be treated not only as a powerful source of vitamin $\mathrm{C}$ but also of carotenoids and polyphenols [3]. Dry herbs and medicinal plants are a perfect source of bioactive compounds, especially polyphenols. The obtained results showed that when we produced herbs with an organic regime, we obtained better products than with conventional food production methods. Among the different herbs, oregano and bear garlic should be considered, especially for their total polyphenol contents. However, it is good to underline that these results were obtained with a two-year experiment. Yearly results are less stable and similar. However, these results provide good guidance for consumers to ensure purchase of high-quality organic dry herbs [4]. Among such important plants for daily infusion preparation are coffee and tea. Nevertheless, new plants with high pro-health properties are always being sought after. The next experiment described and presented in this Special Issue on Organic Food focused on fireweed. The effects of different methods and times of plant material fermentation on the final product quality were examined. The leaves of fireweed were subjected to the following treatments: natural growth and fermentation for different periods as follows: not fermented (control) and fermented for 24 and $48 \mathrm{~h}$. The polyphenols and antioxidant activities in leaves were evaluated using HPLC. The experiment showed that the highest quantities of total phenolic acids and flavonoids were determined after $24 \mathrm{~h}$ under aerobic fermentation, but the amount of total carotenoids was higher after $72 \mathrm{~h}$ of anaerobic fermentation than under the control. Additionally, nonfermented willow herb leaves had a lower antioxidant activity than fermented leaves. In the modern literature, there is scarce information about organic grain quality [5]. The evaluation of a number of barley and oat cultivars produced in an organic system in the next presented experiment met the expectations of producers, who can thus obtain valuable information on selected quality and safety features of individual cultivars, including the content of bioactive compounds, such as polyphenols and carotenoids, and the presence of mycotoxins in the grain [6]. Garlic is one of the most well-known sources of bioactive compounds. For years, it has been used in medicine and food production. The fermentation of garlic from both conventional and organic cultivation significantly increased the content of total polyphenols 
(by more than two times), phenolic acids and flavonoids. The garlic fermentation process also significantly increased its antioxidant potential. The content of bioactive compounds (total polyphenols, phenolic acids, and flavonoids) was significantly higher in organic black garlic than in conventional black garlic. Heat treatment leading to changes in both the physicochemical, organoleptic and health-promoting properties yielded a new product with sensory attractiveness, enabling a wide range of applications [7]. Another experiment with different kinds of garlic showed significant differences between the color of white and black garlic, both in the $\mathrm{L}^{*} \mathrm{a}^{*} \mathrm{~b}^{*}$ and RGB color values, especially in the case of the $\mathrm{L}^{*}$ parameter, indicating that the color of garlic changed from white to dark brown or black during thermal processing. All organic garlic samples had improved bioactive ingredients and antioxidant activity compared to conventional garlic for both fresh (unprocessed) and heat-treated black garlic. The production of black garlic, especially organic garlic, allows one to obtain a product with higher amounts of bioactive compounds, which can be widely used in the design of health-promoting functional foods [8]. The last but still important experiment presented in this Special Issue on Organic Food explored the quality of fruit juices. Juices based on kiwiberries containing over 20 vital nutrients may have potential for usage in developing innovative products targeting health-concerned consumers. The examined juices differed in their patterns of volatile compounds, as well as in their sensory properties and level of liking. The increasing addition of apple and pear juice to kiwiberrybased juices in different ratios contributed to an increase in volatile compounds responsible for floral, sweet and fruity odours. Juice mixes with a higher addition of apple or pear juices are more harmonized in terms of their sensory characteristics and result in higher levels of overall liking among consumers [9].

In summary, the use of organic methods of food production brings benefits both for the environment and for human health.

Funding: References [1,2,4,6-9] financed by the Polish Ministry of Education and Science within funds of the Institute of Human Nutrition Sciences, Warsaw University of Life Sciences (WULS) for scientific research. References [3,5] financed by the Lithuanian Ministry of Education and Science within funds of the Institute of Agriculture and Food Sciences, Agriculture Academy, Vytautas Magnus University for scientific research.

Acknowledgments: This publication was only possible with the invaluable contributions from the authors, reviewers, and the editorial team of Applied Sciences.

Conflicts of Interest: The author declares no conflict of interest.

\section{References}

1. Sadowska, A.; Świderski, F.; Hallmann, E. Bioactive, Physicochemical and Sensory Properties as Well as Microstructure of Organic Strawberry Powders Obtained by Various Drying Methods. Appl. Sci. 2020, 10, 4706. [CrossRef]

2. Średnicka-Tober, D.; Barański, M.; Kazimierczak, R.; Ponder, A.; Kopczyńska, K.; Hallmann, E. Selected antioxidants in organic vs. conventionally grown apple fruits. Appl. Sci. 2020, 10, 2997. [CrossRef]

3. Medveckienė, B.; Kulaitienè, J.; Jarienè, E.; Vaitkevičienè, N.; Hallman, E. Carotenoids, Polyphenols, and Ascorbic Acid in Organic Rosehips (Rosa spp.) Cultivated in Lithuania. Appl. Sci. 2020, 10, 5337. [CrossRef]

4. Hallmann, E.; Sabała, P. Organic and Conventional Herbs Quality Reflected by Their Antioxidant Compounds Concentration. Appl. Sci. 2020, 10, 3468. [CrossRef]

5. Lasinskas, M.; Jariene, E.; Vaitkeviciene, N.; Kulaitiene, J.; Najman, K.; Hallmann, E. Studies of the variability of polyphenols and carotenoids in different methods fermented organic leaves of Willowherb (Chamerion angustifolium (L.) Holub). Appl. Sci. 2020, 10, 5254. [CrossRef]

6. Kazimierczak, R.; Średnicka-Tober, D.; Leszczyńska, D.; Nowacka, A.; Hallmann, E.; Barański, M.; Kopczyńska, K.; Gnusowski, B. Evaluation of phenolic compounds and carotenoids content and mycotoxins occurrence in grains of seventeen barley and eight oat cultivars grown under organic management. Appl. Sci. 2020, 10, 6369. [CrossRef]

7. Najman, K.; Sadowska, A.; Hallmann, E. Influence of Thermal Processing on the Bioactive, Antioxidant, and Physicochemical Properties of Conventional and Organic Agriculture Black Garlic (Allium sativum L.). Appl. Sci. 2020, 10, 8638. [CrossRef]

8. Najman, K.; Sadowska, A.; Hallmann, E. Evaluation of Bioactive and Physicochemical Properties of White and Black Garlic (Allium sativum L.) from Conventional and Organic Cultivation. Appl. Sci. 2021, 11, 874. [CrossRef]

9. Kostyra, E.; Król, K.; Knysak, D.; Piotrowska, A.; Żakowska-Biemans, S.; Latocha, P. Characteristics of volatile compounds and sensory properties of mixed organic juices based on kiwiberry fruits. Appl. Sci. 2021, 11, 529. [CrossRef] 